Noel Loos, Invasion and Resistance: Aboriginal-European Relations on the North Queensland Frontier 1861-1897, Brisbane: Boolarong Press, 2017, 344 pp.,

ISBN 978192552 2600,

A\$29.99.-ERRATUM

\title{
Alyssa Madden
}

DOI: https://doi.org/10.1017/qre.2018.31; Published by Cambridge University Press, $11^{\text {th }}$ December 2018.

In the above mentioned book review by Alyssa Madden, an error to the word 'resources' has been introduced on line 29.

The following sentence:

This chapter outlines ways in which Anglo settlers dispossessed the Aboriginal inhabitants of Queensland in order to exploit the state's natural res" autoources.

Should read:

This chapter outlines ways in which Anglo settlers dispossessed the Aboriginal inhabitants of Queensland in order to exploit the state's natural resources.

The publisher apologises for this error.

\section{Reference}

Madden, A. 2018. Noel Loos, Invasion and Resistance: Aboriginal-European Relations on the North Queensland Frontier 1861-1897, Brisbane: Boolarong Press, 2017, 344 pp., ISBN 978192552 2600, A\$29.99. Queensland Review 25(2): 322-323. doi: 10.1017 /qre.2018.31 